$\underline{\xi}=-m$

\title{
Studies on the effects of cephradine and colibacellosis on immunological status of broiler chicken vaccinated with newcastle virus vaccine
}

\author{
Ashraf Elkomy¹, Mohamed Aboubakr ${ }^{1 *}$, Elsayed Emam², Mohammed Kassem³ \\ ${ }^{1}$ Pharmacology Department, Faculty of Veterinary Medicine, Benha University, 13736, Moshtohor, Toukh, Qalioubeya, Egypt \\ ${ }^{2}$ Animal Health Research Institute (Zagazig branch), Egypt. ${ }^{3}$ Elanco Animal Health, New Cairo, Egypt \\ *Corresponding author E-mail: mohamed.aboubakr@fvtm.bu.edu.eg
}

\begin{abstract}
The present study was carried out using 100, one-day old broiler chicks to evaluate the immunological status of broiler chicks vaccinated with Newcastle virus vaccine and infected with E coli and treated by cephradinee.At day $15^{\text {th }}$ of age, broilers chicks were divided into 4 equal groups ( 25 chicks in each). 1st group, healthy non infected non treated broilers (control group). 2nd, 3rd and 4th groups expermintally infected with E. coli was done at 15th day of age. 2nd group infected, non treated broilers, 3rd group infected broilers and vaccinated with Newcastle disease virus vaccine, 4th group infected broilers vaccinated with Newcastle vaccine and received $20 \mathrm{mg} / \mathrm{kg}$ b.wtcephradinee in drinking water daily for 5 consecutive days. At 1st, 10th and 20th day post administration, blood samples were collected for determination cellular and humeral immune response. Infected broilers with E coli only or infected broilers and vaccinated display significant increase in leukocyte, heterophils, phagocytic activity, phagocytic index, killing percentage, nitric oxide, lysozyme activity and gamma globulin. Beside significant decrease in lymphocyte, serum total protein, albumin, total globulin, A/G ratio and HI titer coupled with insignificant decrease in esinophils, basophils and monocyte, beta globulin associated with insignificant increase in alpha globulin allover experimental period post vaccination when compared with control broilers. Vaccinated-Infected broilers that received $20 \mathrm{mg} / \mathrm{kg}$ b.wtcephradine daily for five consecutive days revealed significant increase in leukocyte, heterophils, phagocytic activity, phagocytic index, killing $\%$ and gamma globulin at 1 st day post treatment coupled with insignificant increase at 10th and 20th day post treatment. In-addition to significant decrease in serum total protein, albumin, total globulin A/G ratio and HI associated with non significant decrease in esinophils, basophils, monocyte, beta globulin and non significant increase in nitric oxide, lysozyme activity and alpha globulin allover the experiment when compared with control broilers. It could be concluded that, colibacillosis in broiler chickens and cephradine induced some adverse effects on immunological status of broiler chickens. Therefore, it's important not vaccinated broiler during colibacelosis or using cephradine in treatment.
\end{abstract}

Keywords: Broiler chickens; Cephradine; Colibacillosis; Immunity; Vaccine.

\section{Introduction}

Cephalosporins are a group of antibiotics derived from mould of cephalosporium spp. and are based on 7-aminocephalosporic acid which crrosponds to 6-penicilanic acid in penicillins (El-Hewaity et al., 2014). Cephradinee is a beta-lactam, first-generation cephalosporin antibiotic with bactericidal activity and available in both oral and parenteral dosage forms (Wilson and Gisvold, 1982).Cephradinee have a good activity against $\mathrm{Gr}+\mathrm{ve}$ bacteria and moderate activity against some enterobacteria as strains of E coli, Proteus mirabilis, Salmonella and Shegella (James, 1993).Antibacterial activity due to ability of beta-lactamase ring to bind bacterial enzyme transpeptid-ase, which important for proper cell wall synthesis (Thomson et al., 1984; El Sayed et al., 2016; Aboubakr and Elbadawy, 2017).

Escherichia coli, usually abbreviated to E.coli, is one of the main species of bacteria normally inhabitants lower intestines of wormblooded animals (birds and mammals) (Rosario et al., 2004). Colibacillosis affects poultry industrycausing serious economic losses achieved by high mortality and lossbody weight (El-Nemr, 2011). Colibacillosis was associated with various disease conditions (Otaki, 1995). Acute form in poultry leads to septicemia and death (Calnek et al., 1997). E.coli infection in poultry associated with pericarditis, perihepatitis, airsacculitis, peritonitis, panophthalmitis and omphalitis (La Ragione and Woodward, 2002).

Newcastle disease is an economically essential listed and highly frequent isolated worldwide virus due to its importance to the commercial poultry producers. Controlling of Newcastle disease virus by vaccination is and routinely applied by the majority of poultry production companies to supply immunological response against the disease (Darrell et al., 2013). The presentwork was conducted to throw light on the effect of E- coli infection and cephradine on immunological status of broilers during vaccination with Newcastle virus vaccine. 


\section{Materials and methods}

\subsection{Drugs}

Cephradinee (Atocef Forte) ${ }^{\circledR}$ water-soluble powder Each $100 \mathrm{gm}$ of powder contain $20 \mathrm{gm}$ cephradinee base. It is available as package containing $500 \mathrm{gm}$. It is produced by ATCO Pharma Company, Egypt.

\subsection{Experimental broiler chickens}

One hundred apparently healthy one day old Hubbard broiler chicks obtained from Cairo Poultry Company (CPC) were used in the present study. Chicks were floor reared under hygienic measures. Chicks were fed on balanced commercial ration free from any medications from Cairo Poultry Comp and water provided ad-libitum.

\subsection{Newcastle vaccine}

Avipro ${ }^{\circledR}$ Polybanco (Live Vaccine against Newcastle-Bronchitis B1 Type, B1 Strain, Mass. \& Conn) Manufactured by Elanco animal health Co. was used as eye drops for vaccination of chicks on the $7^{\text {th }}$ day of age against Newcastle disease.

Avipro ${ }^{\circledR}$ ND-chick (Killed Newcastle disease virus, B1 type, Lasota strain produced by Elanco Co.) given SC. at 7th day old

\subsection{Microorganisms and e. coli inoculum}

E.coli strain $(\mathrm{O} .157)$ used in this study obtained from animal healthy research doki. Broth culture was standardized to give bacterial suspens-ion containing $3 \mathrm{X} 10^{9}$ viable organism/ml of E.coli $\mathrm{O} 157$ using Mac-Ferland tube. Each bird was given $0.3 \mathrm{ml}$ via nasal route (Nakamura et al., 1992).

\subsection{Experimental design}

100 one-day-old Hubbard broiler chicks were divided in to four equal groups ( 25 chicks in each). $1^{\text {st }}$ group; healthy broilers nonvaccinated non medicated served as control. $2^{\text {nd }}, 3^{\text {rd }}$ and $4^{\text {th }}$ groups expermintally infected with E.coli was done at the $15^{\text {th }}$ day of age. $2^{\text {nd }}$ group infected, non-treated broiler chickes (+ve control) $3^{\text {rd }}$ group infected broilers vaccinated with Newcastle disease vaccine only, $4^{\text {th }}$ group infected broilers vaccinated with Newcastle disease virus vaccine and received $20 \mathrm{mg} / \mathrm{kg} \mathrm{b}$.wtcephradine daily for five consecutive days.

At $1^{\text {st }}, 10^{\text {th }}$ and $20^{\text {th }}$ day post treatment 2 blood samples was collected. $1^{\text {st }}$ sample was collected in test tub contain EDTA as anticoagulant for estimation total and differential leucocytic count according to Jain (1986). Phagocytic activity, Phagocytic index and killing \% were determined according to Rouse et al., (1980) and Woldehiwet and Rowan (1990). $2^{\text {nd }}$ sample was collected in test tub for obtain clear serum for estimation serum total protein according to Doumas et al., (1981), protein fractions were performed using cellulose acetate electrophoresis test according Henry et al., (1974). Serum Nitric oxide was measured according to Rajarman et al., (1998) and Ramadan and Attia (2003) and lysozyme activity (Schltz, 1987).

\subsection{Statistical analysis}

Obtaineddata was analyzed (Petrie and Watson 1999).

\section{Results}

Infected broilers with $E$ coli only or infected broilers and vaccinated display significant increase in leukocyte, heterophils, phagocytic activity, index, killing percentage, nitric oxide, lysozyme and $\gamma$ globulin. In-addition to significant decrease in lymphocyte, total protein, albumin, globulin and HI titer coupled with insignificant decrease in eosinophils, basophils, monocyte and $\beta$ globulin associated with insignificant increase in $\alpha$ globulin allover experimental period post vaccination.

Vaccinated-Infected broilers, received $20 \mathrm{mg} / \mathrm{kg}$ b.wt cephradine daily for five days showed significant increase in leukocyte, heterophils, phagocytic activity, index, killing $\%$ and $\gamma$ globulin at $1^{\text {st }}$ day post treatment coupled with insignificant increase at $10^{\text {th }}$ and $20^{\text {th }}$ day post treatment. More-over significant decrease in total protein, albumin, total globulin and HI titers associated with insignificant decrease in eosinophils, basophils, monocyte, $\beta$ globulin and insignificant increase in nitric oxide, lysozyme and $\alpha$ globulin allover experiment.

\section{Discussion}

Broiler chickens infected with $E$ coli only or infected and vaccinated with Newcastle vaccine evoked significant leukocytosis, heterophilia and significant lymphocyteopenia coupled with insignificant decrease in eosinophil, basophile and monocyte allover the experimental period. Leukocytosis in E coli infected bird may be due to inflammatory response in gastrointestinal tract due to bacterial infection (Doxey, 1983). Our results agreed with El-Nemr (2011) and Allam et al., (2014) they noticed that chickens infected with E. coli showed leucocytosis, heterophilia and lymphocytopenia associated with non significant decrease in eosinophil, basophil and monocyte count. Same change in leukogram was reported by Haq et al., (2015) in pigeons infected with E coli. Our result was parallel with result reported by Mohamed and Younis(2018) stated that colibacelosis induce leucocytosis due to heterophilia

Infected broilers with $E$ coli, cephradinee treated and vaccinated displayed significant leukocytosis and heterophilia beside significant lymphocytopenia at $1^{\text {st }}$ day post treatment and insignificant effect in leukocyte, heterophils and lymphocte at $10^{\text {th }}$ and $20^{\text {th }}$ day post treatment associated with insignificant decrease in esinophils, basophils and monocyte allover the experiment(Abd El-Aziz, 2006). These results are reinforced by Hassan (1996) who stated that rabbits infected with E coli treated with cefoperazone showed no harmful effects in leukogram. Our data clearly reinforced by those obtained by Mwafy (2000) who stated that another cephalosporin (Ceftiofur) im- 
proved adverse effects of E. coli infection on leukogram. Same changes in leukogram were reported by Shawky (2007) who stated that infected broilers with E coli cefoperazone treated improved leukogram.

Broilers infected with $E$ - coli only or infected with E- coli and vaccinated displayed significant increase in phagocytic activity and index compared with control broilers. Same change in phagocytosis \% and index was recorded in broiler infected with E. coli (Coles, 1986). These results were in agreement with those of El-Boushy et al., (2006) and EL-Sissi and Salman (2011) who stated that phagocytic activity and index were increased in E. coli infection in broilers. Our results go hand in hand with those obtained by Abd El-Ghany and Ismail (2014) and Allam et al., (2014) who stated that, E. coli infection induced elevation in phagocytic activity in broilers. Colibacelosis in broilers revealed significant elevation in phagocytic activity and killing \% (Awad et al., 2015; Mohamed and Younis, 2018).

Chickens infected with $E$ coli, cephradine treated and vaccinated with Newcastle vaccine displayed significant increase in phagocytic activity, index and killing $\%$ at $1^{\text {st }}$ day coupled with insignificant increase at $10^{\text {th }}$ and $20^{\text {th }}$ day post vaccination. Another cephalosporin (Cefodizime) capable of interfering with some bacteria as $E$ coli virulence parameters, thus facilitating host neutrophilic defenses such as phagocytosis, killing and oxidative bursts (Braga et al., 1999). Same changes in phagocytic activity, index and killing \% were reported by Abd El hafez et al., (2006) in rabbits infected with E coli and treated with cefotaxime.

Broilers infected with $E$ coli or vaccinated with Newcastle vaccine and infected with $E$ coli displayed significant increase in nitric oxide and lysozyme activity allover the experimental period post infection.Nitric oxide and lysozyme increased in some bacterial infection and it acts as a free radical (Bredt and Snyder, 1994). This result comes in accordance with those of Tizard (1996) who reported that endotoxin excreted by $E$. coli induced increase in nitric oxide and lysozyme. Incereasd Nitric oxide and lysozyme in bacterial infection is involved in innate immunity (Coleman, 2001). Chicken infected with E. coli infection and vaccinated with Newcastle vaccine induced increased in Nitric oxide in infected broilers and plays an important role in destroying invading microorganisms (Foley and Farrell, 2003). Same results were supported by Nakamura et al., (1994) who reported that chicken vaccinated with live Newcactle vaccine and infected with E coli showed increase in lysozyme.

Chickens infected with $E$ coli, cephradine treated and vaccinated with Newcastle vaccine displayed insignificant increase in nitric oxide and lysozyme allover the experimental period post infection. Same observation was reported by Abd El hafez et al., (2006) who reported that infected rabbits with $\mathrm{E}$ coli treated with cefotaxime and vaccinated with another vaccine (hemorrhagic septicemia vaccine) induced insignificant increase in nitric oxide and lysozyme. Same changes in nitric oxide and lysozyme were reported by Huang and Matsumoto (2000) in chickens infected with $E$. coli and vaccinated with Newcastle disease virus vaccine.

Infected broilers with $E$. coli only or with vaccination displayed significant decrease on serum total protein, albumin, total globulin, A/G ratio and significant increase in $\gamma$ globulin allover experimental period post infection coupled with insignificant increase in $\alpha$ beside insignificant decrease in $\beta$ globulin. Our findings were reinforced by El-Nemr (2011) which indicated that broiler chickens infected with $E$. coli showed significant decrease in serum total proteins, albumin and significant increase in globulins.This finding is in accordance with the finding of Yassin (2012) and Zaki et al., (2012) they found that serum total protein, albumin, and A/G ratio were significantly decreased associated with increase in globulin in broilers infected with E. coli.Our data coincides with El Sayed et al., (2014) and Mohamed (2015) who found that colibacelosis induced significant reduction in serum total protein and albumin. This result was supported by Kumari (2016) and Godbole (2017) reported that broiler chicks experimentally infected E. coli revealed decrease in total protein and albumin concentration.

Infected chickens treated with cephradine or infected treated with cephradine and vaccinated showed significant decrease in serum total protein, albumin, total globulin and $\mathrm{A} / \mathrm{G}$ ratio. Beside significant increase in serum $\gamma$ globulin at $1^{\text {st }}$ day post vaccination associated with non significant effect at $10^{\text {th }}$ and $20^{\text {th }}$ day post vaccination coupled with insignificant increase in $\alpha$ and insignificant decrease in $\beta$ globulin allover experimental period post vaccination when compared with control broiler chickens. Same changes were reported by Borowski et al., (1984) who stated that cephalosporins induced significant decrease in serum total protein, albumin, total globulin and A/G ratio. Our results were supported by results reported by Ahmad (2009) who mentioned that broiler vaccinated by Newcastle vaccine and received ceftifur sodium showed significant decrease in serum total protein, albumin, total globulin and A/G ratio beside significant increase in serum $\gamma$ globulin. Same results were reported by Hegazy et al., (2006) who reported that broiler infected with E. coli and Newcastle disease vaccination revealed insignificant increase in $\alpha$ and insignificant decrease in $\beta$ globulin.

Our results revealed that $E$. coli infection alone or $E$. coli infection and vaccination in broilers produced significant reduction in HI titers allover experimental period post infection. Meanwhile, infected with $E$. coli, Cephradine treated and vaccinated with Newcastle vaccine elicited significant decrease in HI titers at $1^{\text {st }}$ day post vaccination coupled with insignificant decrease at $10^{\text {th }}$ and $20^{\text {th }}$ day post treatment when compared with control broilers. Reduction in HI titers against Newcastle disease might be attributed to the immunosuppressive effect of E. coli. Colibacelosis in chickens induced vaccination failure immune response of chickens to Newcastle virus vaccine and induces significant reduction in HI titers against Newcastle disease (Hassan and Hassanein, 1999).The obtained results were in agreement with El-Sissi and Mohamed (2011) who reported that broilers infected with E. coli showed significant reduction in HI titers for Newcastle disease virus. Our observed data are in accordance with those reported by Abd El-Ghany and Ismail (2014) who stated that, E. coli infection induced reduction in HI titers for Newcastle disease virus in broilers. Our data coordinates with those recorded by Awad et al., (2015) who recorded that $E$. coli infection decreased HI titers humoral immune responses to Newcastle disease viruses.

Table 1: Effect of Vaccination and Cephradine (20 mg/Kg B.Wt) on Total and Differential Leucocytic Count of Broilers (N=5)

\begin{tabular}{|c|c|c|c|c|c|c|c|c|c|c|c|c|c|}
\hline \multirow{2}{*}{\multicolumn{2}{|c|}{ Parameter }} & \multicolumn{4}{|c|}{$1^{\text {st }}$ day } & \multicolumn{4}{|c|}{$10^{\text {th }}$ day } & \multicolumn{4}{|c|}{$20^{\text {th }}$ day } \\
\hline & & G 1 & G 2 & G 3 & G 4 & G 1 & G 2 & G 3 & G 4 & G 1 & G 2 & G 3 & G 4 \\
\hline \multirow{2}{*}{\multicolumn{2}{|c|}{$\begin{array}{l}\text { T. leukocyte } \\
10^{3} / \mathrm{ul}\end{array}$}} & $11.21 \pm$ & $12.18 \pm$ & $11.76 \pm$ & $11.69 \pm$ & $11.27 \pm$ & $12.25 \pm$ & $11.78 \pm$ & $11.27 \pm$ & $11.26 \pm$ & $12.27 \pm$ & $11.85 \pm$ & $11.49 \pm$ \\
\hline & & 0.15 & $0.31 *$ & $0.13^{*}$ & $0.12 *$ & 0.16 & $0.34^{*}$ & $0.19 *$ & 0.27 & 0.18 & $0.36^{*}$ & $0.20^{*}$ & 0.21 \\
\hline \multirow{9}{*}{ 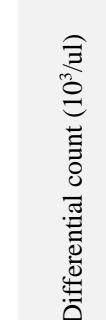 } & & $2.40 \pm$ & $3.69 \pm$ & $3.84 \pm$ & $2.79 \pm$ & $2.44 \pm$ & $3.79 \pm$ & $3.79 \pm$ & $2.65 \pm$ & $2.43 \pm$ & $3.66 \pm$ & $3.45 \pm$ & $2.45 \pm$ \\
\hline & Hetero. & 0.18 & $0.42 *$ & $0.50 *$ & $0.1^{*}$ & 0.19 & $0.38^{*}$ & $0.42 *$ & 0.28 & 0.18 & $0.31 *$ & $0.30 *$ & 0.19 \\
\hline & & $4.25 \pm$ & $3.90 \pm$ & $3.84 \pm$ & $3.93 \pm$ & $4.30 \pm$ & $3.99 \pm$ & $3.80 \pm$ & $4.20 \pm$ & $4.35 \pm$ & $3.93 \pm$ & $3.89 \pm$ & $4.22 \pm$ \\
\hline & Lymph & 0.11 & $0.0^{*}$ & $0.11^{*}$ & $0.08 *$ & 0.10 & $0.09 *$ & $0.16^{*}$ & 0.17 & 0.11 & $0.11^{*}$ & $0.10^{*}$ & 0.19 \\
\hline & Fsing & $1.36 \pm$ & $1.30 \pm$ & $1.35 \pm$ & $1.35 \pm$ & $1.39 \pm$ & $1.31 \pm$ & $1.34 \pm$ & $1.40 \pm$ & $1.37 \pm$ & $1.33 \pm$ & $1.35 \pm$ & $1.36 \pm$ \\
\hline & & $1.52 \pm$ & $1.36 \pm$ & $1.39 \pm$ & $1.53 \pm$ & $1.51 \pm$ & $1.37 \pm$ & $1.36 \pm$ & $1.49 \pm$ & $1.50 \pm$ & $1.35 \pm$ & $1.37 \pm$ & $1.50 \pm$ \\
\hline & Baso. & 0.12 & 0.17 & 0.17 & 0.18 & 0.14 & 0.15 & 0.18 & 0.19 & 0.11 & 0.19 & 0.19 & 0.20 \\
\hline & Mono & $1.65 \pm$ & $1.58 \pm$ & $1.44 \pm$ & $1.49 \pm$ & $1.68 \pm$ & $1.59 \pm$ & $1.49 \pm$ & $1.50 \pm$ & $1.68 \pm$ & $1.47 \pm$ & $1.49 \pm$ & $1.50 \pm$ \\
\hline & Mono. & 0.24 & 0.26 & 0.27 & 0.21 & 0.26 & 0.27 & 0.16 & 0.20 & 0.28 & 0.28 & 0.19 & 0.26 \\
\hline
\end{tabular}

\footnotetext{
* Significant at $\mathrm{P}<0.05$.
} 
Table 2: Effect of Vaccination and Cephradine $(20 \mathrm{mg} / \mathrm{Kg} \mathrm{B.Wt})$ on Phagocytic Activity Percentage, Phagocytic Index, Killing Percentage of Broilers $(\mathrm{N}=5)$

\begin{tabular}{|c|c|c|c|c|c|c|c|c|c|c|c|c|}
\hline \multirow{2}{*}{ Parameter } & \multicolumn{4}{|l|}{$1^{\text {st }}$ day } & \multicolumn{4}{|l|}{$10^{\text {th }}$ day } & \multicolumn{4}{|l|}{$20^{\text {th }}$ day } \\
\hline & $\mathrm{Gp} 1$ & $\mathrm{Gp} 2$ & Gp 3 & $\mathrm{Gp} 4$ & Gp 1 & $\mathrm{Gp} 2$ & $\mathrm{Gp} 3$ & $\mathrm{Gp} 4$ & $\mathrm{Gp} 1$ & $\mathrm{Gp} 2$ & Gp 3 & $\mathrm{Gp} 4$ \\
\hline phagocytic & $40.13 \pm$ & $42.03 \pm$ & $41.95 \pm$ & $41.38 \pm$ & $40.15 \pm$ & $42.87 \pm$ & $41.67 \pm$ & $40.67 \pm$ & $40.1 \pm$ & $42.95 \pm$ & $41.81 \pm$ & $40.70 \pm$ \\
\hline activity\% & 0.54 & $0.51^{*}$ & $0.39^{*}$ & $0.30^{*}$ & 0.41 & $0.49^{*}$ & $0.42 *$ & 0.90 & 0.59 & $0.53^{*}$ & $0.40^{*}$ & 0.69 \\
\hline phagocytic & $4.86 \pm$ & $5.96 \pm$ & $5.86 \pm$ & $5.68 \pm$ & $4.86 \pm$ & $5.99 \pm$ & $5.80 \pm$ & $4.94 \pm$ & $4.80 \pm$ & $5.94 \pm$ & $5.88 \pm$ & $4.98 \pm$ \\
\hline index & 0.46 & $0.23^{*}$ & $0.15^{*}$ & $0.14^{*}$ & 0.39 & $0.24 *$ & $0.14^{*}$ & 0.39 & 0.38 & $0.22 *$ & $0.20 *$ & 0.25 \\
\hline killing $\%$ & $76.39 \pm$ & $78.89 \pm$ & $78.90 \pm$ & $78.09 \pm$ & $76.43 \pm$ & $78.95 \pm$ & $78.98 \pm$ & $76.77 \pm$ & $76.37 \pm$ & $78.94 \pm$ & $78.96 \pm$ & $76.46 \pm$ \\
\hline K1Iling\% & 0.43 & $0.73^{*}$ & $0.79^{*}$ & $0.59 *$ & 0.49 & $0.71^{*}$ & $0.83^{*}$ & 0.46 & 0.26 & $0.83^{*}$ & $0.81 *$ & 0.69 \\
\hline
\end{tabular}

* Significant at $\mathrm{P}<0.05$.

Table 3: Effect of Vaccination and Cephradine (20 mg/Kg B.Wt) on Serum Nitric Oxide and Serum Lysozyme Activity of Broilers (N=5)

\begin{tabular}{|c|c|c|c|c|c|c|c|c|c|c|c|c|}
\hline \multirow{2}{*}{ Parameter } & \multicolumn{4}{|c|}{$1^{\text {st }}$ day } & \multicolumn{4}{|c|}{$10^{\text {th }}$ day } & \multicolumn{4}{|c|}{$20^{\text {th }}$ day } \\
\hline & G 1 & G 2 & G 3 & G 4 & G 1 & G 2 & G 3 & G 4 & G 1 & G 2 & G 3 & G 4 \\
\hline \multirow{2}{*}{ Nitric oxide } & $26.16 \pm$ & $29.18 \pm$ & $29.21 \pm$ & $27.37 \pm$ & $27.11 \pm$ & $29.18 \pm$ & $29.05 \pm$ & $27.49 \pm$ & $27.06 \pm$ & $29.15 \pm$ & $29.17 \pm$ & $27.29 \pm$ \\
\hline & 0.76 & $0.8 *$ & $0.71 *$ & 0.41 & 0.39 & $0.80 *$ & $0.58 *$ & 0.34 & 0.43 & $0.51 *$ & $0.62 *$ & 0.53 \\
\hline $\begin{array}{l}\text { lysozyme ac- } \\
\text { tivity }\end{array}$ & 1.04 & $0.91 *$ & $1.26^{*}$ & 1.53 & 1.10 & $1.21 *$ & $1.14^{*}$ & 1.29 & 1.12 & $1.32 *$ & $1.20 *$ & 1.61 \\
\hline
\end{tabular}

* Significant at $\mathrm{P}<0.05$.

Table 4: Effect of Vaccination and Cephradine (20 mg/Kg B.Wt) on Serum Total Protein and Protein Fractions of Broiler Chickens (N=5)

\begin{tabular}{|c|c|c|c|c|c|c|c|c|c|c|c|c|c|}
\hline \multirow{2}{*}{\multicolumn{2}{|c|}{ Parameter }} & \multicolumn{4}{|c|}{$1^{\text {st }}$ day } & \multicolumn{4}{|c|}{$10^{\text {th }}$ day } & \multicolumn{4}{|c|}{$20^{\text {th }}$ day } \\
\hline & & G 1 & $\mathrm{G} 2$ & G 3 & G 4 & G 1 & $\mathrm{G} 2$ & G 3 & G 4 & G1 & G 2 & G 3 & $\mathrm{G} 4$ \\
\hline \multirow{3}{*}{\multicolumn{2}{|c|}{$\begin{array}{l}\text { T. protein } \\
\text { (gm/dl) } \\
\text { Albumin } \\
(\mathrm{gm} / \mathrm{dl})\end{array}$}} & $5.57 \pm$ & $4.99 \pm$ & $5.06 \pm$ & $5.12 \pm$ & $5.54 \pm$ & $5.09 \pm$ & $5.43 \pm$ & $5.54 \pm$ & $5.58 \pm$ & $5.10 \pm$ & $5.49 \pm$ & $5.63 \pm$ \\
\hline & & 0.33 & $0.41 *$ & $0.46^{*}$ & $0.15 *$ & 0.11 & $0.45^{*}$ & $0.31 *$ & 0.39 & 0.14 & $0.39 *$ & $0.35^{*}$ & 0.61 \\
\hline & & 0.21 & $0.22 *$ & $0.18 *$ & $0.18 *$ & 0.22 & $0.14 *$ & $0.19 *$ & 0.29 & 0.26 & $0.10^{*}$ & $0.11 *$ & 0.32 \\
\hline \multirow{2}{*}{\multicolumn{2}{|c|}{$\alpha$}} & $0.63 \pm$ & $0.64 \pm$ & $0.63 \pm$ & $0.64 \pm$ & $0.62 \pm$ & $0.69 \pm$ & $0.66 \pm$ & $0.69 \pm$ & $0.60 \pm$ & $0.66 \pm$ & $0.68 \pm$ & $0.66 \pm$ \\
\hline & & 0.13 & 0.04 & 0.05 & 0.04 & 0.15 & 0.08 & 0.08 & 0.08 & 0.13 & 0.08 & 0.07 & 0.08 \\
\hline$\widehat{\theta}$ & \multirow{2}{*}{$\beta$} & $0.85 \pm$ & $0.81 \pm$ & $0.84 \pm$ & $0.81 \pm$ & $0.86 \pm$ & $0.84 \pm$ & $0.85 \pm$ & $0.84 \pm$ & $0.85 \pm$ & $0.83 \pm$ & $0.84 \pm$ & $0.83 \pm$ \\
\hline$\underbrace{00}_{0}$ & & $1.20 \pm$ & $1.51 \pm$ & $1.45 \pm$ & $1.49 \pm$ & $1.22 \pm$ & $1.53 \pm$ & $1.72 \pm$ & $1.28 \pm$ & $1.26 \pm$ & $1.57 \pm$ & $1.69 \pm$ & $1.29 \pm$ \\
\hline$\Xi$ & $\gamma$ & 0.04 & $0.11 *$ & $0.08 *$ & $0.10 *$ & 0.05 & $0.12 *$ & $0.17 *$ & 0.08 & 0.03 & $0.1^{*}$ & $0.13 *$ & 0.09 \\
\hline है & \multirow{4}{*}{ Total } & $2.68 \pm$ & $2.96 \pm$ & $2.95 \pm$ & $2.94 \pm$ & $2.70 \pm$ & $3.06 \pm$ & $3.26 \pm$ & $2.81 \pm$ & $2.73 \pm$ & $206 \pm$ & $3.24 \pm$ & $2.78 \pm$ \\
\hline$\widetilde{J}$ & & 0.21 & $0.06 *$ & $0.03 *$ & $0.13 *$ & 0.10 & $0.11 *$ & $0.19 *$ & 0.19 & 0.10 & $0.10^{*}$ & $0.16^{*}$ & 0.16 \\
\hline $\mathrm{A} / \mathrm{G}$ & & $1.08 \pm$ & $0.69 \pm$ & $0.72 \pm$ & $0.74 \pm$ & $1.05 \pm$ & $0.66 \pm$ & $0.67 \pm$ & $0.97 \pm$ & $1.06 \pm$ & $0.67 \pm$ & $0.69 \pm$ & $1.06 \pm$ \\
\hline Ratio & & 0.16 & $0.13^{*}$ & $0.14^{*}$ & $0.12 *$ & 0.19 & $0.19^{*}$ & $0.13^{*}$ & 0.13 & 0.17 & $0.14 *$ & $0.13^{*}$ & 0.16 \\
\hline
\end{tabular}

* Significant at $\mathrm{P}<0.05$.

\section{References}

[1] Abd El hafez, S.; Manal, B. and Amer, H. (2006) Enhancement the Efficacy of Cephalosporins with E Coli Periplasmic Protein to Control E. ColiInfection with Special Reference to Pneumonic Manifestations. SCVMJ, X (1), 415-428.

[2] Abd El-Aziz, M. (2006):Handbook of Veterinary Pharmacology, 5th Ed.

[3] Abd El-Ghany, W. and Ismail, M. (2014) Tackling experimental colisepticae-mia in broiler chickens using phytobiotic essential oils and antibiotic alone or in combination. Iranian J Vet Res, Shiraz Uni 15(2)110-115.

[4] Abdallah, SA. (2015) Influence of cephalexin on Immuno status of vaccinated Rabbits. MVSc. Thesis Dept. of Bird and Rabbit Diseases, Fac. Vet. Med, Zag. University.

[5] Aboubakr, M and Elbadawy M (2017) Bioavailability, pharmacokinetics and tissue residues of cephradine (Atocef Forte $\left.{ }^{\circledR}\right)$ in healthy and colisepticemic broiler chickens. International Journal of Pharmacology and Toxicology, 5 (1): 57-60 https://doi.org/10.14419/ijpt.v5i1.7428.

[6] Ahmad, S (2009) effect of certifier sodium (excenel) on immune response of vaccinated chickens. PhD Theses submitted to Fac of Vet Med.Zag Uni.

[7] Allam, H; Eman, S; Salah, H Rashidy, R. and Adel, E. (2014) Effect Organic Acidsand Probiotic on broiler Blood Parameters and Control of E. coli. Zag.Vet. J. 42:1.

[8] Awad A., El-Hofy, FI; Khalid I and El-Shora HE. (2015) Effect of Synbiotic on immune response of experimentally infected broiler chickens with E. coli and salmonella. Benha Vet. Med. J. 28. 2:188-194https://doi.org/10.21608/bvmj.2015.32501.

[9] Borowski, J.; Jakoniok, P. and Talarczyk, J. (1984): The influence of some cephalosporins as immunological response. Antibiotic (Tokoyo), 37(12):719-726.

[10] Braga, P.; Dal Sasso, M.; Mancini, L. and Sala, M. (1999): Influence of sub-minimum inhibitory concentrations of cefodizime on phagocytosis, Intracellular killing and oxidative Bursts of human polymorpho-nuclear leukocytes. Chemotherapy. J., 45(3): 166174.https://doi.org/10.1159/000007179.

[11] Bredt, D. and Snyder, S. (1994): Nitric oxide, a physiological messenger molecule. Ann Rev Biochem 63: 175-195 https://doi.org/10.1146/annurev.bi.63.070194.001135.

[12] Calnek, B.; Barnes, H.; Beard, C.; McDougald, L. and Saif Y. (1997) Diseases of Poultry. 10 ${ }^{\text {th }}$ ed. Iowa State University Press; Ames, IA, USA.

[13] Coleman, J. (2001) Nitric oxide in immunity and inflammation. Int. Immunopharmacol. 1: 1397-1406https://doi.org/10.1016/S15675769(01)00086-8.

[14] Coles, E (1986). Veterinary Clinical Pathology. (EH Cole, editor), Fourth edition. WB Saunders, New York. Pp 43-72.

[15] Darrell R.; Claudio L. and Patti J. (2013) Immune responses of poultry to Newcastle disease virus.Developmental \& Comparative Immunology, 41(3): 47-53https://doi.org/10.1016/j.dci.2013.04.012.

[16] Deng, R.; Xu, Y. and Yu, N. (1991) Dynamic study on antibody-forming cells and antibody-secreting cells in the initial stage post immunization with Rabbit hemorrhagic disease vaccine (in Chinese). Sci. agric. Sinica, 24 (1), 21-30.

[17] Doumas, B.; Cartor, R.; Peers, T. and Schaffer, R. (1981): Acandidate reference method for determination of total protein in serum Clin Chem, 27, 1642.

[18] Doxey, D (1983): Clinical pathology and diagnostic procedure $2^{\text {nd }}$ Ed.Baillier London.

[19] El Sayed, M.; Allam, H.; El Nabarawy, E. and Eman, S. (2014): bioche-mical and bacteriological studies on mortality in newly born rabbits. Zag. Vet. J. 42 (3) 56-66. 
[20] EL Sayed, M.G.; Aboubakr, M and Rabea, S (2016) Pharmacokinetics and tissue residues of cephradine in healthy and experimentally Salmonella entretidis infected broiler chickens. World Journal of Pharmacy and Pharmaceutical Sciences. 6 (6): 61-74.

[21] El-Boushy, M; Sanaa, S and Abeer, H (2006): Immunological and biochemical studies onpefloxacin in broilers infected with E. coli. Proc. of $8^{\text {th }}$ Sci. Vet Med Zag Conf.PP: 55-59

[22] El-Hewaity $\quad$ M, Abd $\quad$ El $\quad$ Latif $\quad$ A, Soliman $\quad$ A, Aboubakr $\quad$ M. $\quad$ (2014) Comparative Pharmacokinetics of Cefquinome (Cobactan 2.5\%) following RepeatedIntramuscular Administrations in Sheep and Goats. $\quad \mathrm{J} \quad$ Vet Med.2014:949642. https://doi.org/10.1155/2014/949642.

[23] EL-Kadeem, A.M. (2005): Pharmacological studies of gentamicin and ciproflo-xacin in colibacillosis in chickens. MVSc. Thesis, Fac. Vet. Med., Zagazig Uni.

[24] El-Nemr, AE. (2011):Efficacyof florfenicol on E coli infection in chicken.Thesis presented to Fac. of Vet. Med.Cairo. Uni. for the degree of Ph.D.

[25] El-Sissi, Ashgan, F. and Mohamed, SH (2011): Impact of synbiotic on immune response of broilers against NDV vaccines. Global J of Biot and Bioch. 6 (4): 186-191

[26] Foley, E. and Farrell, P. (2003): Nitric oxide contributes to induction of innate immune responses to Gr-ve bacteria in Drosophila. Foley \& FarrellGenes \&Develo. 17: 115- 125.https://doi.org/10.1101/gad.1018503.

[27] Godbole, P. (2017): evaluation of prophylactic and therapeutic efficacy of curcumin against escherichia coli-induced infection in broiler chicks. Master Thesis Submitted to Maharashtra Animal and Fishery Sciences Uni, Nagpur (India) (Vet Pharmacology).

[28] Haq, K.; Khan, S. and Nabi, G. (2015) Efficacy of Clarithromycin and Cefpod-oxime Against Colibacillosis in Pigeons. Ame- Eurasian J of Toxic Sci. 7(2):72-82.

[29] Hassan, M. and Hassanein, Z. (1999): Effect of E coli on the immune response of chickens to Newcastle virus vaccine. J. Egypt. Vet. Med. Assoc. 59: 75-91.

[30] Hegazy, A.; Eid, A.; Abdel-Aleem, I.; Youssef, B.; Nasser, A. and Hany, A. (2006) studies on E. coli infection in chickens and immune response after Newcastle disease vaccination. $8^{\text {th }}$ Sci. Vet. Med. Zag. , Conf. 231-239

[31] Henry, R.; Cannon, D. and Winkelman, J. (1974) Clinical Chemistry Principals and tec- hniques p 437 - 440, Harper and Row, Hagerstown.

[32] Huang, H. and Matsumoto, M. (2000): Non-specific innate immunity against E coli infection in chickens induced by Newcastle disease vaccine. Avian Disease. 44:790-796.https://doi.org/10.2307/1593050.

[33] Jain, N (1986): Schalm's veterinary Haematology $4^{\text {th }}$ Ed p. 55-96 Lee and Febiger, Philadelphia, U.S.A.

[34] James, E. (1993). Martindale, the extra pharmacopoeia, Royal Pharmaceutical Society, London. $30^{\text {th }}$ Ed;

[35] Jeon, W.; Lee, E. and Lee, Y (2008) Protective efficacy of Newcastle vaccines in chickens against a recent Korean epizootic strain. J of Vet Sci. 9(3): 25-30. https://doi.org/10.4142/jvs.2008.9.3.295.

[36] Kaneko J (1989) Biochemistry of domestic animal Acad. Pres Inc New York.

[37] Kumari, M. (2016) Pathological and immunological studies on Escherichia coli infection in broiler chickens fed on Withaniasomnifera and Aloe vera extracts. Ph.D. thesis submitted to Lala Lajpat Rai Uni of Vet Sci.

[38] La Ragione R. and Woodward M. (2002) Virulence factors of E. coli serotypes associated with avian coli septicemia. Res. Vet. Sci. 73:2735. https://doi.org/10.1016/S0034-5288(02)00075-9.

[39] Mohamed HMA and Younis W (2018) Trials on the Role of Probiotics in Colonization and Immune Response of Broilers Challenged with E Coli K88. Alex J of Vet Sci. 58 (1): 48-56https://doi.org/10.5455/ajvs.297887.

[40] Mohamed, D. (2015) efficacy and residues of doxycycline in ducks infected with E. coliMVSc.Thesis (Pathology Fac. of Vet. Med., Zag Uni.)

[41] Mwafy, RM. (2000): Pharmacological profile of concurrent use of some antimicrobials in chickens. MVSc Thesis presented to Fac. Vet. Med., Zag Unvi.

[42] Nakamura, K. Ueda, H. Tanimura, T. and Noguchi, K. (1994):Effect of mixed live vaccine (Newcactle disease) and Mycoplasma gallisepticum on the chicken respiratory tract and on Escherichia coli infection. J. Comp. pathol. 111:33-42.https://doi.org/10.1016/S0021-9975(05)80109-4.

[43] Otaki Y. (1995) Poultry disease control in Japan. Asian Livestock. 20: 65-67.

[44] Petrie,A and Watson,P.(1999):“ Statistics for Veterinary and Animal Science.“1 stEd. PP. 90 - 99. The Black well Sc. Ltd. United Kingdom.

[45] Rajaraman, V.; Nonnecke, B.; Franklin, S. and Horst, R. (1998): Effect of vitamins A and E on nitric oxide production by blood mononuclear leukocytes from neonatal calves fed milk replacer. J Dairy Sci., 81:378-385https://doi.org/10.3168/jds.S0022-0302(98)75892-8.

[46] Ramadan, A and Attia, E (2003): Natural killing molecules in cervical mucus of buffaloes during estrous cycle. $7^{\text {th }}$ Sci. Cong. Egypt. Soci. for cattle dis, Assiut.

[47] Rosario, C; Lopaz, A.; Tellez, I.; Navarro, O and Eslava, C (2004): Serotyping and virulence genes detection in E coli isolated from fertile and infertile eggs, dead-in-shell embryos and chickens with yolk sac infection. Avian Dis; 48 (4):81-89.https://doi.org/10.1637/7195-041304R.

[48] Rouse, B.; Babiuk, L. and Henson, P. (1980): Neutrophils in antiviral inhibition of virus replication of mediators produced by bovine neutrophils.J.Inf. Dis 141(2)23- 32https://doi.org/10.1093/infdis/141.2.223.

[49] Schltz, L (1987): Methods in Clinical Chemistry.The CV Mosby cost Louis, 42- 46

[50] Shawky, NA. (2006): Antibacterial efficacy of cefoperazone and sulbactam in chickens. Thesis presented to Fac. Vet. Med. Zag. Uni. for Ph.D. degree "pharmacology"

[51] Thomson, T; Quay, J and Webber, J (1984): Cephalosporin group of antimicr-robial drugs. J. Am. Vet. Med. Ass. 185(10):1109- 1114

[52] Tizard, I. (1996): "Veterinary immunology. An Introduction." $5^{\text {th }}$ Ed., WB Saunders Comp, A division of Harcourt Brace Comp, London, Toronto, Monterialo, Sedny, Tokyo

[53] Wang, X; Zhou, Q; Shen, J and Yang, X (2015): Effect of Newcastle disease vaccine immunization on growth performance and immune response of broilers. J. Anim. Sci. and Bio, 6(1): 20. https://doi.org/10.1186/s40104-015-0019-y.

[54] Wilson, A and Gisvold, T (1982): Textbook of organic medicinal and pharmaceutical chemistry. $8^{\text {th }}$ edition,

[55] Woldehiwet, Z and Rowan, T (1990): effects of age of calves on phagocytosis and killing of Staph aureus by polymorph nuclear leucocytes. Br. Vet J. 146: 65- 70.https://doi.org/10.1016/0007-1935(90)90009-R.

[56] Yassin, EM. (2012): SomeImmunochemical studies on microbial exposure of Rabbits. M.Sc. Thesis Zagazig Uni. Fac. of Vet. Med. Dep. of Biochemistry.

[57] Zaki, M; Fawzy, O and Osfor, M (2012): Effect of E. coli 0157 on Baladi Broiler Chicken and some Biochemical studies. Life Sci. J. 9(1): 91-94. 